\title{
PENINGKATAN KOMPETENSI PEDAGOGIS GURU BERBASIS KETERAMPILAN DASAR MENGAJAR DI MI NURUL KARIM NW KEBON AYU GERUNG LOMBOK BARAT
}

\author{
Abdul Fattah \\ Universitas Islam Negeri Mataram \\ fath_smart@yahoo.com
}

\begin{abstract}
Abstrak: Artikel ini memaparkan peningkatan kompetensi pedagogis guru berbasis keterampilan dasar mengajar di MI Nurul Karim NW Kebon Ayu Gerung. Madrasah ini telah berdiri sejak 30 tahun lalu, namun masih banyak menghadapi hambatan, terutama berkaitan dengan masalah kualifikasi dan kompetensi guru. Kompetensi guru MI Nurul Karim NW Kebon Ayu telah dilakukan pembinaan dan pengembangan secara fungsional, sehingga memiliki kompetensi yang tinggi, terutama dalam hal kompetensi pedagogis dasar bagi seorang guru, yang meliputi komptensi membuka dan menutup pelajaran, keterampilan bertanya, keterampilan menjelaskan, dan sebagainya. Dalam kegiatan pembekalan-pelatihan ini dimaksudkan untuk memberikan orientasi dengan tujuan memberikan wawasan dan pengetahuan bagi segenap guru MI Nurul Karim NW Kebon Ayu yang menjadi peserta sebanyak 15 orang tentang konsep-konsep upaya peningkatan kompetensi pedagogis guru berbasis keterampilan dasar mengajar yang mutakhir. Kegiatan ini dalam penerapannya menggunakan metode ceramah, diskusi maupun latihan tugas tentang berbagai penting terkait kompetensi pedagogis guru. Termasuk dalam hal ini adalah konsep hypnoteaching dalam pembelajaran sebagai bagian dari metode menjelaskan. Sedangkan pendampingan merupakan kegiatan sebagai follow up dari kegiatan pembekalan-pelatihan agar guru yang berjumlah 15 orang selaku peserta tersebut benar-benar memiliki skill terbaru yang terkait dengan kepentingan implementasi kompetensi pedagogis guru berbasis keterampilan dasar mengajar.
\end{abstract}

Kata Kunci: kompetensi pedagogis, hypnoteaching, keterampilan dasar mengajar

\begin{abstract}
This article describes the improvement of teacher pedagogical competencies based on basic teaching skills at MI Nurul Karim NW Kebon Ayu Gerung. This madrasa has been established since 30 years ago, but still faces many obstacles, especially related to the problem of teachers' competence. The competence of teachers at Nuron Karim NW in Kebon Ayu has been improved and developed through a functional way so that they have high competence, especially in pedagogical competencies which includes competence to open and close lessons, asking skills, explaining skills, and so on. The training program was intended to provide orientation by providing insights and knowledge to fifty teachers of Kebon Ayu MI Nurul Karim NW about the concepts of teacher pedagogical competency improvement based on the latest basic teaching skills. This program in its application uses lecture methods, discussions and exercises on various important tasks related to teacher pedagogical competence including the concept of hypnoteaching in learning as part of the method of explaining. While mentoring is a follow-up activity so that the participants really has the latest skills related to the importance of implementing teacher pedagogical competencies based on basic teaching skills.
\end{abstract}

Keywords: paedagogical competence, hypnoteaching, basic teaching skills

\section{Pendahuluan}

Pada era globalisasi, abad informasi, dan teknologi, yang terbayang dalam pikiran bersama adalah aspek kesiapan bangsa Indonesia pada era tersebut. Terlebih pada tahun 2015, memasuki fase "Masyarakat Ekonomi ASEAN (MEA)", bangsa ini tertantang untuk dapat menapakinya secara mulus, benar, dan dalam kerangka kerja yang fairplay. Namun, kegamangan demikian pantas muncul di permukaan, karena dilihat dari sisi sumber daya 
manusia Indonesia, seperti dalam penilaian Suyanto dan Abbas, bangsa ini masih pantas untuk disebut memprihatinkan. ${ }^{1}$ Lebih lanjut, dapat diungkap bahwa kini dunia pendidikan Indonesia mengalami kesuraman bahkan bisa disebut semakin carut-marut. ${ }^{2}$

Atas dasar itu, Tilaar menulis sebagai berikut:

Era abad 21 adalah era ilmu pengetahuan dan teknologi. Tanpa support ilmu pengetahuan dan teknologi, suatu masyarakat akan tertinggal dari perubahan. Oleh sebab itu, negaranegara baik negara maju maupun negara berkembang, memberikan perhatian yang tinggi terhadap pendidikan, khususnya pendidikan sains dan pengembangan teknologi. ${ }^{3}$

Banyak pihak menyadari bahwa pendidikan mempunyai peranan yang sangat strategis dalam pembangunan bangsa. Berbagai kajian di banyak negara menunjukkan kuatnya hubungan antara pendidikan dengan tingkat perkembangan bangsa-bangsa tersebut yang ditunjukkan oleh berbagai indikator ekonomi dan sosial budaya. Pendidikan yang mampu memfasilitasi perubahan adalah pendidikan yang merata, bermutu, dan relevan dengan kebutuhan masyarakat. Sehingga tidak berlebihan jika dikemukakan bahwa peningkatan mutu pendidikan, tampaknya masih merupakan isu sentral beberapa tahun ke depan atau mungkin untuk selamanya. ${ }^{4}$ Agar pembangunan pendidikan dapat berkontribusi terhadap peningkatan kualitas sumber daya manusia (SDM), terdapat tiga syarat utama yang harus diperhatikan yaitu: sarana gedung, buku yang memadai dan berkualitas, serta guru dan tenaga kependidikan yang profesional. ${ }^{5}$

Undang-Undang Republik Indonesia No. 20 tahun 2003 tentang Sistem Pendidikan Nasional mengemukakan bahwa pendidikan nasional bertujuan mengembangkan potensi peserta didik agar menjadi manusia yang beriman dan bertaqwa terhadap Tuhan Yang Maha Esa, berakhlak mulia, sehat, berilmu, cakap, kreatif, mandiri, dan menjadi warga negara yang demokratis serta bertanggungjawab dalam rangka mencerdaskan kehidupan bangsa. ${ }^{6}$ Untuk mencapai tujuan tersebut pemerintah telah menetapkan tiga rencana strategis yaitu: pertama, perluasan dan peningkatan akses; kedua, peningkatan mutu, relevansi dan daya saing; ketiga peningkatan tata kelola pendidikan, transparansi dan akuntabilitas pelaksanaan pendidikan.

Mengingat peran guru yang begitu besar dalam proses pembelajaran, maka diperlukan guru yang profesional, kreatif, inovatif, mempunyai kemauan yang tinggi untuk terus belajar, melek terhadap teknologi informasi, sehingga mampu mengikuti perkembangan zaman. Tuntutan profesionalisme guru terus didengungkan oleh berbagai kalangan di masyarakat kita, termasuk kalangan guru sendiri melalui berbagai organisasi guru yang ada, di samping tuntutan perbaikan taraf hidup guru. Mereka berharap, untuk meningkatkan mutu dan kualitas pendidikan di Indonesia, diperlukan seorang guru yang profesional dalam mendidik siswa-

\footnotetext{
${ }^{1}$ Suyanto dan M.S. Abbas, Wajah dan Dinamika Pendidikan Anak Bangsa (Yogyakarta: Adicita Karya Nusa, 2004), h. 25.

2 Nurrahmah, Potret Buram Pendidikan Daerah Miskin di Indonesia: Becermin dari Dompu Nusa Tenggara Barat (Mataram: Insan Madani Institute Mataram, 2014), h. 1.

${ }^{3}$ H.A.R. Tilaar, Perubahan Sosial dan Pendidikan: Pengantar Pedagogik Transformatif untuk Indonesia (Jakarta: PT Grasindo, 2002), h. 51.

${ }^{4}$ Robinson Situmorang, "Strategi Pembelajaran Berbasis Multiple Intelligence (MI) untuk Pencapaian Kompetensi dalam Pembelajaran", dalam Mozaik Teknologi Pendidikan, eds. Dewi Salma Prawiradilaga dan Eveline Siregar (Jakarta: Kencana, 2008), h. 59.

${ }^{5}$ E. Mulyasa, Menjadi Guru Profesional (Bandung: Remaja Rosdakarya, 2005), h. 3.

${ }^{6}$ Farida Sarimaya, Sertifikasi Guru Apa, Mengapa dan Bagaimana? (Bandung: CV.Yrama Widya, 2008), h. 112.
} 
siswinya di sekolah. Sejalan dengan tuntutan profesionalisme guru itulah, maka pemerintah mengeluarkan Undang-Undang Nomor 14 tahun 2005 tentang Guru dan Dosen. Dengan dikeluarkannya Undang-Undang tersebut guru diposisikan sebagai suatu profesi sebagaimana profesi dokter, hakim, jaksa, akuntan, dan profesi-profesi lain yang akan mendapat penghargaan sepadan sesuai dengan profesinya masing-masing.

Dalam UU No. 14 Tahun 2005: Pasal 1. Guru adalah pendidik profesional dengan tugas utama mendidik, mengajar, membimbing, mengarahkan, melatih, menilai dan mengevaluasi peserta didik pada pendidikan anak usia dini, pendidikan dasar, dan pendidikan menengah pada jalur pendidikan formal.7 Guru mempunyai kedudukan sebagai tenaga profesional pada jenjang pendidikan dasar, pendidikan menengah, dan pendidikan anak usia dini pada jalur formal yang diangkat sesuai dengan peraturan perundang-undangan (UU No. 14 Tahun 2005: Pasal 2 Ayat 1). ${ }^{8}$ Pengakuan kedudukan guru sebagai tenaga profesional seperti yang dimaksudkan di atas dibuktikan dengan sertifikasi pendidik (UU No. 14 Tahun 2005: Pasal 2 Ayat 2). ${ }^{9}$

Faktor tenaga kependidikan khususnya di Pendidikan Dasar masih banyak yang belum memiliki ijazah Stara Satu (S1). Oleh karena itu, Kementerian Agama RI memiliki upaya membantu para guru melalui program beasiswa bagi yang memenuhi persyaratan agar dapat mengikuti perkuliahan di tempat yang ditentukan oleh Kementerian Agama. Guru di lingkungan Kementerian Agama yang bertugas di MI, MTs, MA berjumlah 524.543 orang. Dari jumlah tersebut guru MI dan PAI menempati peringkat pertama dari segi kuantitas. Fenomena di atas terjadi juga pada institusi Pendidikan di Provinsi NTB semisal sekolah/madrasah.

Fenomena buram kehidupan institusi sekolah/madrasah yang dieksplanasikan di atas, sesungguhnya juga terjadi di Madrasah Ibtidaiyah NW Nurul Karim Kebon Ayu, Kecamatan Gerung, Kabupaten Lombok Barat. Berdasarkan survey awal (Bulan Maret - Mei 2017), terutama pada saat memonitor pelaksanaan mahasiswa PPL-2 Fakultas Ilmu Tarbiyah dan Keguruan IAIN Mataram (saat itu belum beralih status menjadi UIN), ditemukan bahwa keadaan manajemen madrasah masih banyak yang harus dibenahi. Hal yang ditekankan di sini juga adalah kompetensi pedagogis guru yang masih terdapat sedang menempuh pendidikan S1. Sedangkan yang lainnya guru yang mengajar bukan dari pendidikan S1 keguruan.

Melalui kegiatan dokumentasi, observasi, dan wawancara dengan kepala madrasah Bpk. Mukrim, S.Pd.I, terungkap bahwa MI Nurul Karim NW Kebon Ayu Gerung merupakan MI swasta, dan berdiri pada tahun 1994 dengan SK Pendirian no: WX/89.122 TS/2/1994. Madrasah ini memiliki tenaga pendidik atau guru yang diangkat oleh yayasan sebanyak 18 orang guru, dan tidak memiliki guru PNS. Latar belakang pendidikan guru sangat beragam, dengan kualifikasi akademik: 8 orang S1, 5 orang D2, dan 5 orang SMA/MA. Dari semua itu, yang berlatar belakang ilmu kependidikan berjumlah 3 orang dan non kependidikan sebanyak 5 orang. ${ }^{10}$

MI Karim NW Kebon Ayu Gerung yang meski telah berdiri sejak 23 tahun lalu, namun masih banyak menghadapi hambatan, terutama berkaitan dengan masalah kualifikasi dan

\footnotetext{
${ }^{7}$ Ibid., h. 113.

${ }^{8}$ Ibid., h. 116.

${ }^{9}$ Ibid., h. 116.

10 Wawancara, Jum'at 27 Mei 2017.
} 
kompetensi guru. Kompetensi guru MI Nurul Karim NW Kebon Ayu Gerung perlu dilakukan pembinaan dan pengembangan secara fungsional, sehingga memiliki kompetensi yang tinggi, terutama dalam hal kompetensi pedagogis dasar bagi seorang guru, yang meliputi komptensi membuka dan menutup pelajaran, keterampilan bertanya, keterampilan menjelaskan, dan sebagainya. Terlebih dimaksimalkan dengan penguasaan metode terbaru, yaitu metode "Hypnoteaching" dalam pembelajaran bagi Para Guru MI Nurul Karim NW Kebon Ayu Gerung.

\section{Metode}

Metode yang digunakan dalam pelaksanaan kegiatan pengabdian ini adalah sebagai berikut:

1. Memberi penjelasan dan pemahaman kepada guru MI Nurul Karim NW Kebon Ayu Gerung oleh narasumber tentang berbagai keterampilan dasar mengajar esensial yang harus dimiliki guru. Dilakukan dengan menggunakan metode ceramah, tanyak jawab, diskusi, brain storming terkait dengan pokok materi tentang konsep-konsep / teori dan komponenkomponen keterampilan dasar mengajar. Terhadap sekian banyak keterampilan dasar mengajar tersebut, diberikan kebebasan dan alternatif kepada guru untuk memilih dan menggunakan secara integratif dalam pelaksanaan kegiatan pembelajaran, agar berhasil secara baik.

2. Latihan praktik/pendampingan. Cara ini merupakan tindak lanjut dan sebagai follow up dari cara yang pertama. Guru akan didampingi dan diarahkan dalam penyusunan perangkap pembelajaran (RPP) yang terkait dengan implementasi berbagai keterampilan dasar mengajar. Pemahaman guru yang baik tentang keterampilan dasar mengajar, tidak menjamin guru secara otomatis dapat menerapkannya dengan baik. Untuk dapat menjamin penerapan keterampilan dasar mengajar yang baik, penting dilakukan pendampingan sebagai wujud nyata untuk meningkatkan komptensi guru sampai benar-benar guru memiliki kompetensi tinggi sesuai dengan yang diinginkan.

\section{Hasil dan Pembahasan}

\section{Konsep Profesionalisme Keguruan}

Peningkatan kompetensi guru merupakan salah satu bagian dari ciri guru yang professional. Berbicara mengenai profesionalisme keguruan maka tidak terlepas dari definisi profesionalisme itu sendiri.

"Profesionalisme berasal dari bahasa inggris professionalism yang secara leksikal berarti sifat profesional. Menurut Jasin profesionalisme dapat diartikan sebagai komitmen para anggota suatu profesi untuk meningkatkan kemampuan profesionalnya dan terus menerus mengembangkan strategi-strategi yang digunakannya dalam pekerjaan dalam melakukan pekerjaan sesuai dengan profesinya". ${ }^{11}$

Lebih lanjut lagi Saudagar dan Ali menjelaskan tentang profesionalisme bahwa:

"Profesionalisme adalah kondisi, arah, nilai, tujuan, dan kualitas suatu keahlian dan kewenangan yang berkaitan dengan mata pencaharian. Maka pengertian profesionalisme

${ }^{11}$ Fachruddin Saudagar dan Ali Idrus. "Pengembangan Profesionalitas Guru". (Jakarta: Gaung Persada (GP Press), 2009) h. 96. 
merujuk kepada komitmen sebagai anggota suatu profesi untuk meningkatkan kemampuan profesionalnya secara terus menerus". ${ }^{12}$

Dengan mengacu pada pendapat para ahli di atas dapat dipahami bahwa profesionalisme merupakan suatu komitmen yang dilakukan oleh seorang guru dalam melaksanakan tugas dan tanggung jawabnya sebagai tenaga pendidik. Senada dengan hal di atas maka jabatan tenaga pendidik bukan hanya menuntut kemampuan spesialisasi tenaga pendidik dalam arti menguasai pengetahuan akademik dan kemahiran profesional yang relevan dengan bidang serta tugasnya sebagai tenaga pendidik, tetapi juga tingkat kedewasaan dan tanggung jawab serta kemandirian yang tinggi dalam mengambil keputusan. ${ }^{13}$

1. Pengembangan Profesionalisme Keguruan

Menurut Sudarwan dalam Saudagar dan Ali menjelaskan tentang pengembangan profesional tenaga pendidik bahwa:

"Pengembangan profesional tenaga pendidik dimaksudkan untuk memenuhi tiga kebutuhan, pertama, kebutuhan sosial untuk meningkatkan kemampuan sistem pendidikan yang efisien dan manusiawi, serta melakukan adaptasi untuk menyusun kebutuhan-kebutuhan sosial. Kedua, kebutuhan untuk menemukan cara-cara untuk membantu staf pendidikan dalam rangka mengembangkan pribadinya secara luas. Dengan demikian tenaga pendidik dapat mengembangkan potensi sosial dan potensi akademik generasi muda dalam interaksinya dalam alam lingkungannya. Ketiga, kebutuhan untuk mengembangkan dan mendorong keinginan tenaga pendidik untuk menikmati dan mendorong keinginan pribadinya, seperti halnya dia membantu peserta didiknya dalam mengembangkan keinginan dan keyakinan untuk memenuhi tuntutan pribadi yang sesuai dengan potensi dasarnya". ${ }^{14}$

Dalam versi yang berbeda, Soetjipto dan Kosasi mengemukakan ada dua cara model pengembangan profesionalisme guru yaitu pengembangan sikap selama pendidikan prajabatan dan pengembangan sikap selama dalam jabatan. ${ }^{15}$

2. Kompetensi Keguruan

Menurut Usman dalam Saudagar dan Ali menjelaskan bahwa:

"Kompetensi adalah suatu hal yang menggambarkan kualifikasi atau kemampuan seseorang, baik yang kualitatif maupun yang kuantitatif. Kemampuan kualitatif seseorang adalah kemampuan sikap dan perbuatan seseorang yang hanya dapat dinilai dengan ukuran baik dan buruk. Sedangkan kuantitatif adalah kemampuan seseorang yang dapat dinilai dengan ukuran (terukur)". ${ }^{16}$

Sejalan dengan itu Saudagar dan Ali menjelaskan lebih rinci tentang kompetensi yaitu sejumlah kemampuan yang harus dimiliki guru untuk mencapai tingkatan guru profesional. Kompetensi guru meliputi kompetensi pedagogik, kompetensi profesional, kompetensi

\footnotetext{
12 Ibid, h. 97

${ }^{13}$ Ibid., h. 98-99.

${ }^{14}$ Fachruddin saudagar dan Ali Idrus, Pengembangan Profesionalitas Guru... h. 99-100.

${ }^{15}$ Soetjipto dan Kosasi, Profesi Keguruan (Jogjakarta: CV Wicaksaana, 2012) h. 54-55.

${ }^{16}$ Fachruddin saudagar dan Ali Idrus, Pengembangan Profesionalitas Guru... h. 30.
} 
kepribadian, dan kompetensi sosial. ${ }^{17}$ Adapun kompetensi yang tersebut di atas akan di bahas secara lebih rinci sebagai berikut:

1. Kompetensi Pedagogik

Rumusan kompetensi pedagogik di dalam Penjelasan Peraturan Pemerintah Nomor 19 Tahun 2005, tentang standar nasional pendidikan, pasal 28, ayat 3 yang menyebutkan bahwa kompetensi ialah kemampuan mengelola pembelajaran peserta didik yang meliputi; 1) pemahaman terhadap peserta didik, 2) perancangan dan pelaksanaan pembelajaran, 3) evaluasi hasil belajar.

Berdasarkan beberapa pengertian tersebut di atas dengan kompetensi pedagogik maka guru mempunyai kemampuan-kemampuan sebagai berikut.
a. Menguasai landasan mengajar.
b. Menguasai ilmu mengajar (didaktif metodik).
c. Mengenal siswa.
d. Menguasai teori motivasi.
e. Mengenal lingkungan masyarakat.
f. Menguasai penyusunan kurikulum.
g. Menguasai teknik penyusunan RPP.
h. Menguasai pengetahuan evaluasi pembelajaran dll. ${ }^{18}$

2. Kompetensi Kepribadian

Setiap guru mempunyai pribadi masing-masing sesuai ciri-ciri pribadi yang mereka miliki. ${ }^{19}$ Kompetensi kepribadian mencakup sikap (attitude), nilai-nilai (value) kepribadian (personality) sebagai elemen perilaku (behavior) dalam kaitannya dengan performance yang ideal sesuai dengan bidang pekerjaan yang dilandasi oleh latar belakang pendidikan, peningkatan kemampuan dan pelatihan, serta legalitas kewenangan mengajar.

Menurut Peraturan Pemerintah Nomor 19 Tahun 2005, pada pasal 28, ayat 3 ialah kemampuan kepribadian yang mantap, stabil, dewasa, arif, dan berwibawa, menjadi teladan bagi peserta didik, dan berakhlak mulia. Berdasarkan uraian di atas, maka fungsi kompetensi kepribadian guru adalah memberikan teladan dan contoh dalam membimbing, mengembangkan kreatifitas dan membangkitkan motivasi belajar siswa dalam proses belajar mengajar. Lebih jelas lagi dapat dirinci sebagai berikut:

a. Penampilan sikap yang positif terhadap keseluruhan tugasnya sebagai guru, dan terhadap keseluruhan situasi pendidikan beserta unsur-unsurnya.

b. Pemahaman, penghayatan dan penampilan nilai-nilai yang seyogyanya dianut oleh seorang guru.

c. Penampilan upaya untuk menjadikan dirinya sebagai panutan dan teladan bagi para siswanya. ${ }^{20}$

\footnotetext{
17 Ibid., h. 31

1818 Yudhi Munadi, Media Pembelajaran (Sebuah Pendekatan Baru). (Jakarta: Gaung Persada (GP), 2012), h. 1

${ }^{19}$ Abdul Rahman shaleh, Pendidikan Agama \& Pembangunan Watak Bangsa, (Jakarta: PT Raja Grafindo Persada,

${ }^{20}$ Hanafiah dan Cucu Suhana, Konsep Strategi Pembelajaran, (Bandung : PT Refika Aditama, 2010), h. 106
} 2005), h. 16 
3. Kompetensi sosial

Kompetensi sosial dalam kegiatan belajar ini berkaitan erat dengan kemampuan guru dalam berkomunikasi dengan masyarakat di sekitar sekolah dan masyarakat tempat guru tinggal sehingga peranan dan cara guru berkomunikasi di masyarakat diharapkan memiliki karakteristik tersendiri yang sedikit banyak berbeda dengan orang lain yang bukan guru. Adapun kompetensi sosial yang dimaksud di sini mencakup:

a. Terampil berkomunikasi dengan peserta didik dan orang tua peserta didik.

b. Bersikap simpatik.

c. Dapat bekerja sama dengan dewan pendidikan/ komite sekolah.

d. Pandai bergaul dengan kawan sekerja dan mitra pendidikan.

e. Memahami dunia sekitarnya (lingkungan).

4. Kompetensi Profesional

Kompetensi profesional ialah kemampuan menguasai pengetahuan bidang ilmu, teknologi dan atau seni yang diampunya meliput ipenguasaan;

a. Materi pelajaran secara luas dan mendalam sesuai standar isi program satuan pendidikan, mata pelajaran, dan atau kelompok mata pelajaran yang diampunya.

b. Konsep-konsep dan metode disiplin keilmuan, dan atau seni yang relevan yang secara konseptual menaungi atau koheren dengan program satuan pendidikan, pelajaran, dan atau kelompok mata pelajaran yang akan diampunya. Jadi guru profesional adalah guru yang memiliki kemampuan dan keahlian khusus dalam bidang keguruan sehingga ia mampu melakukan tugas dan fungsinya sebagai guru. Dengan kata lain guru yang profesional adalah orang yang terdidik dan terlatih serta punya pengalaman di bidang keguruan. Sementara itu guru profesional mempunyai sikap dan sifat terpuji adalah sebagai berikut:

1) Bersikap adil.

2) Percaya dan suka kepada siswanya.

3) Sabar dan rela berkorban.

4) Memiliki wibawa di hadapan peserta didik.

5) Penggembira.

6) Bersikap baik terhadap guru-guru yang lainnya.

7) Bersikap baik terhadap masyarakat.

8) Benar-benar menguasai mata pelajaran.

9) Suka dengan mata pelajaran yang diajarkannya

10) Berpengetahuan luas. ${ }^{21}$

Begitu kompleks kompetensi yang harus dimilki oleh seorang guru guna menjadi guru yang profesional. Hal ini dimaksudkan untuk memenuhi tuntutan dalam menjalankan tugas yang diemban dalam mewujudkan mutu pendidikan yang baik, dan untuk meningkatkan kualitas maupun kuantitas pendidikan nasional.

\footnotetext{
${ }^{21}$ Dimyati dan Mudjiono, Belajar dan Pembelajaran (Jakarta: Rineka Cipta, 1999), 12
} 


\section{Upaya Peningkatan Kompetensi Pedagogis Guru}

Salah satu faktor penting yang akan mempengaruhi keberhasilan pembelajaran adalah kemampuan guru dalam mengelola pembelajaran dari awal sampai akhir pembelajaran. Paling tidak, seorang guru yang baik perlu memiliki keterampilan dasar dalam mengajar. Yaitu sebagai berikut:

\section{Keterampilan Membuka Pelajaran}

Kegiatan membuka pelajaran merupakan keterampilan dasar yang harus dan wajib dimiliki oleh guru, dengan keterampilan membuka proses pembelajaran maka seorang guru akan terarah dalam menyampaikan materi yang diajarkan kepada siswanya, ${ }^{22}$ jika pendidik atau guru mampu dan bisa membuka pelajaran dengan baik maka guru tersebut akan mampu mengarahkan siswa sesuai dengan arahan dari guru, akan tetapi jika guru tidak berhasil atau gagal membuka pelajaran dengan baik maka akan berpengaruh terhadap proses penyampaian materi pembelajaran. ${ }^{23}$

Kegiatan membuka pelajaran mempunyai banyak sekali tujuan, diantaranya :

1. Membangkitkan motivasi dan perhatian

2. Membuat siswa memahami batas tugasnya

3. Membantu siswa memahami hubungan berbagai materi yang disajikan

4. Membantu siswa mengetahui tingkat keberhasilannya

Membuka pelajaran adalah kegiatan yang dilakukan guru untuk menciptakan suasana yang dapat mempersiapkan mental, perhatian, dan gambaran tentang apa yang akan dipelajari dan dikuasai siswa sehingga tercipta kondisi awal pelajaran yang terarah dan dinamis, beberapa komponen membuka pelajaran diantaranya : Menarik perhatian siswa dengan berbagai cara, Menimbulkan motivasi dengan cara (1) menciptakan kehangatan dan keantusiasan (2) menimbulkan rasa ingin tahu (3) mengemukakan ide yang bertentangan (4) dan memperhatikan minat siswa, Memberikan acuan dengan cara (1) mengemukakan tujuan dan batas batas tugas (2) menyarankan langkah-langkah yang akan dilakukan (3) mengingatkan masalah pokok yang akan dibahas, dan (4) mengajukan pertanyaan, Membuat kaitan, dengan cara (1) mengajukan pertanyaan apersepsi, atau (2) merangkum pelajaran yang lalu.

\section{Keterampilan Menjelaskan}

Menjelaskan adalah kegiatan untuk menyampaikan informasi atau materi pelajaran dalam tata urutan yang terencana secara sistematis sehingga dengan mudah dapat dipahami oleh siswa. ${ }^{24}$ Kegiatan menjelaskan bertujuan untuk : Membimbing siswa memahami berbagai konsep, hukum, prinsip, atau prosedur, Membimbing siswa menjawab pertanyaan "mengapa" secara bernalar, Melibatkan siswa untuk berfikir, Mendapatkan balikan mengenai pemahaman siswa, Menolong siswa menghayati berbagai proses penalaran.

Keterampilan menjelaskan terdiri dari berbagai komponen sebagai berikut:

a. Komponen merencanakan penjelasan, yang mencakup:

\footnotetext{
${ }^{22}$ Azhar Arsyad. Media Pembelajaran. (Jakarta: PT Raja Grafindo Persada, 2008), h. 15.

${ }^{23}$ Abu Ahmadi dan Nur Uhbiyati, Ilmu Pendidikan, (Jakarta: Rineka Cipta, 1991), h. 6

${ }^{24}$ Azhar Arsyad. Media Pembelajaran...47
} 
1. Isi pesan (pokok-pokok materi)yang dipilih dan disusun secara sistematis disertai contohcontoh

2. Hal-hal yang berkaitan dengan karakteristik penerima pesan (siswa)

b. Komponen menyajikan penjelasan, yang mencakup hal-hal berikut.

1. Kejelasan, yang dapat dicapai dengan berbagai cara, seperti bahasa yang jelas, berbicara lancar, mendefinisikan istilah-istilah teknis, dan berhenti sejenak untuk respons siswa atau penjelasan siswa.

2. Penggunaan contoh dan ilustrasi, yang dapat mengikuti pola induktif atau pola deduktif.

3. Pemberian tekanan pada bagian-bagian yang penting dengan cara: penekanan suaara, membuat ikhtisar, atau mengemukakan tujuan.

4. Balikan tentang penjelasan yang disaji dengan melihat mimik siswa atau mengajukan pertanyaan. ${ }^{25}$

\section{Keterampilan Menutup}

Kegiatan ini dimaksudkan untuk memberikan penegasan, rangkuman, atau kesimpulan, dan pemberian balikan atas respons siswa, keterampilan menutup pelajaran terdiri atas komponen berikut:

a. Meninjau kembali dengan cara merangkum atau membuat ringkasan

b. Mengadakan evaluasi penguasaan siswa, dengan meminta mereka (1) mendemonstrasikan keterampilan, (2) menerapkan ide baru padaa situasi lain, (3) mengekspresikan pendapat sendiri, dan (4) memberikan soal tertulis (5) memberikan tindak lanjut yang dapat berupa pekerjaan rumah, merancang sesuatu atau berkunjung ke suatu tempat.

Perlu diingat bahwa kegiatan membuka dan menutup pelajaran tidak hanya dilakukan pada awal dan akhir kegiatan, tetapi juga pada awal dan akhir setiap penggal kegiatan, dengan catatan bahwa ini harus bermakna dan berkesinambungan

\section{Penerapan Metode Hypnoteaching dalam Pembelajaran}

\section{a. Pengertian Hypnoteaching}

Saat ini, banyak metode pembelajaran yang telah dikembangkan dan diterapkan di sekolahsekolah. Salah satu metode yang saat ini mulai banyak dikembangkan adalah metode pembelajaran Hypnoteaching. Hypnoteaching merupakan metode pembelajaran yang dalam menyampaikan materi, guru memakai bahasa-bahasa bawah sadar yang bias menumbuhkan ketertarikan tersendiri kepada anak didik. Dari asal kata hypnoteaching merupakan perpaduan dua kata, yaitu hypnosis dan teaching. Hypnosis berarti mensugesti dan teaching yang berarti mengajar. Jadi, dapat diartikan bahwa hypnoteaching adalah usaha untuk menghipnosis atau mensugesti anak didik supaya menjadi lebih baik dan prestasinya meningkat.

Menurut Novian Triwidia Jaya ${ }^{26}$, hypnoteaching merupakan perpaduan pengajaran yang melibatkan pikiran sadar dan bawah sadar. Hypnoteacahing ini merupakan metode pembelajaran yang kreatif, unik, sekaligus imajinatif. Sebelum pelaksanaan pembelajaran, para

\footnotetext{
25 Tim FKIP, Pemantapan Kemampuan Mengajar (PKM)- PGSD (Jakarta : Universitas Terbuka, 2008), h. 1.18

${ }^{26}$ Novian Triwidia Jaya, Hypno Teaching "Bukan Sekedar Mengajar"(Bekasi: D-Brain, 2010), h. 41.
} 
anak didik sudah dikondisikan untuk belajar. Dengan demikian, anak didik mengikuti pembelajran dalam kondisi segar dan siap untuk menerima materi pelajaran. Untuk mempersiapkan hal-hal tersebut, tentu guru sendiri juga dituntut untuk stabil baik secara psikologis, maupun secara psikis. Denga begitu, guru pun mempunyai kesiapan yang penuh dalam mengajar para ank didiknya.

Sementara menurut Muhammad Noer ${ }^{27}$, dalam hypnoteaching guru bertindak sebagai penghipnotis, sedangkan anak didik berperan sebagai suyet atau orang yang dihipnotis. Dalam pembelajaran, sebenarnya guru tidak perlu menidurkan anak didiknya ketika memberikan sugesti. Guru cukup menggunakan bahasa yang persuasif sebagai alat komunikasi yang sesuai dengan harapan anak didik. Hal yang harus diingat adalah guru harus berusaha menyampaiakn kepada anak didik dengan bahasa yang mudah dipahami oleh anak didik. Sebab, dengan bahasa yang mudah dipahami oleh anak didik. Sebab, sangat tidak mungkin hypnosis bisa berjalan secara efektif jika suyet tidak paham akan maksud dari penghipnotis. Adapun unsur-unsur yang perlu diketahui dalam hypnoteaching adalah penampilan guru, rasa simpati, sikap yang empatik, penggunaan bahasa, motivasi anak didik dengan cerita atau kisah, peraga (bagi yang kinestetik), dan jika ingin menguasai pikiran anak didik, kuasai terlebih dahulu hatinya. ${ }^{28}$

\section{b. Manfaat Hypnoteaching}

Saat ini kita sering melihat banyak sekolah yang merasa kewalahan dan kesulitan dalam menghadapi berbagai permasalahan yang dialami oleh para anak didiknya. ${ }^{29}$ Mulai dari hal "kecil", seperti malas belajar, tidak bersemangat dalam mengikuti proses pembelajaran, mempunyai prestasi belajar yang rendah, sampai pada penyimpangan-penyimpangan perilaku yang "besar" yang dilakukan oleh anak didik. Bahkan, tidak sedikit dari penyimpangan itu termasuk dalam kenakalan dan tindakan kriminal.

Dari penjelasan sebelumnya, dapat diketahui bahwa metode hypnoteaching hanya bermain pada kekuatan pikiran alam bawah sadar. Melalui penguasaan hypnoteaching, para akan menjadi lebih memahami pola kerja pikiran anak didik yang sebenarnya. Dengan kata lain, kita dapat memahami bahwa hypnoteaching adalah pengemabangan pada metode pembelajaran. Melalui hypnoteaching, guru dapat melakukan pendekatan konseptual yang baru terahadap anak didiknya. Selain itu, metode ini juga memberikan "terapi penyembuhan" pada anak didik yang mempunyai permasalahan belajar maupun psikis. ${ }^{30}$

Adapun beberapa manfaat yang bisa dicapai melalui penerapan metode hypnoteaching dalam pembelajaran di dalam kelas sebagai berikut :

a. Pembelajaran menjadi menyenangkan dan lebih mengasyikkan, baik bagi anak didik, maupun bagi guru.

b. Pembelajaran dapat menarik perhatian anak didik melalui berbagai kreasi permainan yang diterapkan oleh guru.

c. Guru menjadi lebih mampu dalam mengelola emosinya.

\footnotetext{
27 Muhammad Noer, Hypno Teaching for Succes Learning (Yogyakarta: Pustaka Insan Madani, 2010), h. 21.

${ }^{28}$ Ibid, h. 137.

${ }^{29}$ Muhammad Noer, Hypno Teaching for Succes Learning... 112

30 Novian Triwidia Jaya, Hypno Teaching "Bukan Sekedar Mengajar...44
} 
d. Pembelajaran dapat menumbuhkan hubungan yang harmonis antara guru dan anak didik.

e. Guru dapat mengatasi anak-anak yang mempunyai kesulitan belajar melalui pendekatan personal.

f. Guru dapat menumbuhkan semangat anak didik dalam belajar melalui permainan hypnoteaching.

g. Guru ikut membantu anak didik dalam menghilangkan kebiasaan-kebiasaan buruk yang mereka miliki. ${ }^{31}$

\section{Kondisi Komunitas yang Diharapkan}

Berdasarkan hal tersebut, dipandang layak jika kompetensi guru MI Nurul Karim NW Kebon Ayu Gerung terus ditingkatkan, sehingga mampu menjalankan tugas profesinya dengan baik dan berhasil maksimal. Sedangkan murid yang sedang aktif belajar di MI Nurul Karim NW Kebon Ayu Gerung cukup banyak, sebagaimana tertera dalam tabel berikut:

Tabel 2. Data seluruh siswa MI Nurul Karim NW Kebon Ayu Gerung Lombok Barat Tahun Pelajaran 2016/2017. ${ }^{32}$

\begin{tabular}{ccccccccc}
\hline \multirow{2}{*}{$\begin{array}{c}\text { Tahun } \\
\text { Pelajaran }\end{array}$} & \multicolumn{2}{c}{ Kelas 1 } & \multicolumn{2}{c}{ Kelas 2 } & \multicolumn{2}{c}{ Kelas 3 } & \multicolumn{2}{c}{ Jumlah } \\
\cline { 2 - 8 } & $\begin{array}{c}\text { Jml } \\
\text { Siswa }\end{array}$ & $\begin{array}{c}\text { Jml } \\
\text { Rombel }\end{array}$ & $\begin{array}{c}\text { Jml } \\
\text { Siswa }\end{array}$ & $\begin{array}{c}\text { Jml } \\
\text { Rombel }\end{array}$ & $\begin{array}{c}\text { Jml } \\
\text { Siswa }\end{array}$ & $\begin{array}{c}\text { Jml } \\
\text { Rombel }\end{array}$ & $\begin{array}{c}\text { Jml } \\
\text { Siswa }\end{array}$ & $\begin{array}{c}\text { Jml } \\
\text { Rombel }\end{array}$ \\
\hline $2011 / 2012$ & 36 & 1 & 13 & 1 & 27 & 1 & 76 & 3 \\
$2012 / 2013$ & 32 & 1 & 39 & 1 & 34 & 1 & 105 & 3 \\
$2013 / 2014$ & 63 & 2 & 26 & 1 & 27 & 1 & 116 & 4 \\
$2014 / 2015$ & 85 & 3 & 60 & 2 & 26 & 1 & 171 & 6 \\
$2015 / 2016$ & 55 & 2 & 72 & 3 & 44 & 2 & 171 & 7 \\
$2016 / 2017$ & 70 & 3 & 50 & 2 & 63 & 3 & 183 & 8 \\
\hline
\end{tabular}

Atas dasar itu, upaya peningkatan kompetensi guru tidak dapat ditawar-tawar lagi. Hal ini misalnya dapat dilakukan melalui penguasaan berbagai keterampilan dasar mengajar yang harus dikuasai guru. Berbagai keterampilan dasar mengajar dimaksudkan meliputi keterampilan membuka dan menutup pelajaran, keterampilan menjelaskan, keterampilan bertanya, keterampilan mengadakan variasi, keterampilan memberi penguatan, keterampilan mengajar kelompok kecil dan perorangan, keterampilan mengelola kelas, dan keterampilan membimbing diskusi kelompok kecil.

Tujuan pembinaan ini adalah memberikan pemahaman dan kesadaran kepada guru MI Nurul Karim NW Kebon Ayu Gerung (terutama yang tidak berlatar belakang sarjana kependidikan dan atau yang masih D1 dan SMA) tentang pentingnya memiliki kemampuan aplikatif berbagai keterampilan dasar mengajar dalam pelaksanaan pembelajaran. Kemudian meningkatkan kompetensi guru MI Nurul Karim NW Kebon Ayu Gerung, sehingga dapat melaksanakan kegiatan pembelajaran secara baik. Selanjutnya meningkatkan kemampunan penyusunan RPP yang baik dan bertanggung jawab.

\section{Pihak-pihak yang Dilibatkan}

\footnotetext{
31 Djamarah dan Saiful Bahri, Guru dan Anak Didik dalam Interaksi Edukatif(Jakarta: PT Rineka Cipta, 2005), h. 65
}

32 Dokumentasi, MI Nurul Karim NW Kebon Ayu Gerung, 27 Maret 2017. 
Pihak-pihak yang terlibat dalam kegiatan pembinaan madrasah ini antara lain adalah dosen-dosen Fakultas Tarbiyah dan Keguruan (FTK) UIN Mataram yang memiliki kualifikasi atau keahlian di bidang keterampilan dasar mengajar, termasuk yang sudah berkualifikasi selaku asesor. Dalam hal ini yang menjadi narasumber adalah Drs.H. Baehaqi, M.Pd., Dr. H. Maimun, M.Pd. dan Rusni bil Makruf, M.Pd.I. Keterlibatan dosen-dosen ini adalah dalam rangka memberikan pemahaman kepada guru-guru oleh narasumber tentang keterampilan dasar mengajar serta melakukan pembinaan secara bertahap. Selanjutnya yang terlibat dalam kegiatan ini (yang menjadi peserta) adalah seluruh guru MI Nurul Karim NW Kebon Ayu Gerung yang berjumlah 15 orang. Rinciannya 5 orang guru yang sudah berpendidikan S1 non kependidikan, yaitu (Mukrim, SE, Mahwan, SE, Asmayani. SH, Suherni Mahani, SIP, dan Hernawati, SE). Selebihnya sebanyak 10 orang guru yang belum menuntaskan (masih dalam proses) pendidikan S1, yaitu Izzuddin, Uswatun Khasanah, Endalaini, Apna, Dedi Satriawan, Fauzi, Nurhamidah, Muslimah, Hasanuddin, dan Kamahar. Mereka telah terlibat aktif dalam proses pelatihan, pembinaan, mulai dari strategi yang pertama hingga yang terakhir. Termasuk dimonitor pelaksanaan praktik berkala dengan berbagai keterampilan dasar mengajar bagi guru MI, mulai dari keterampilan membuka dan menutup pelajaran, keterampilan menjelaskan, keterampilan bertanya, keterampilan mengadakan variasi, keterampilan memberi penguatan, keterampilan mengajar kelompok kecil dan peroarangan, keterampilan mengelola kelas, dan keterampilan membimbing diskusi kelompok kecil. Begitu juga praktik secara simultan terkait dengan kemampuan mengajar, terutama pada saat menjelaskan dengan menggunakan strategi "hypnoteaching" dalam menjelaskan pembelajaran. Di luar narasumber dari Fakultas Tarbiyah dan Keguruan UIN Mataram, para guru MI Nurul Karim NW Kebon Ayu Gerung yang berkualifikasi S1 Kependidikan turut serta dilibatkan, terutama pada saat praktik secara simultan, sesuai dengan instrumen keterampilan dalam pembelajaran yang ada.

\section{Instrumen Pengabdian}

Di dalam kegiatan pembinaan kompetensi pedagogis guru berbasis keterampilan dasar mengajar di MI Nurul Karim NW Kebon Ayu, Kecamatan Gerung, Kabupaten Lombok Barat, instrumen yang telah digunakan sebagai standar praktik bagi guru-guru yang sedang dibina adalah instrumen penilaian kegiatan praktik mengajar (peer teaching) dalam kegiatan PLPG menggunakan Kurikulum 2013 dengan pendekatan saintifik.

\section{Strategi Pembinaan Upaya Peningkatan Kompetensi Pedagogis Guru Berbasis Keterampilan Dasar Mengajar}

Dalam kegiatan pembekalan-pelatihan ini dimaksudkan untuk memberikan orientasi dengan tujuan memberikan wawasan dan pengetahuan bagi segenap guru MI Nurul Karim NW Kebon Ayu-Gerung yang menjadi peserta sebanyak 15 orang tentang konsep-konsep upaya peningkatan kompetensi pedagogis guru berbasis keterampilan dasar mengajar yang mutakhir. Kegiatan ini dalam penerapannya menggunakan metode ceramah, diskusi maupun latihan tugas tentang berbagai penting terkait kompetensi pedagogis guru. Termasuk dalam hal ini adalah konsep hypnoteaching dalam pembelajaran sebagai bagian dari metode menjelaskan. 
Sedangkan pendampingan merupakan kegiatan sebagai follow up dari kegiatan pembekalanpelatihan. Di mana peserta akan didampingi untuk menata dan menghasilkan berbagai skill terbaru yang terkait dengan kepentingan implementasi kompetensi pedagogis guru berbasis keterampilan dasar mengajar, serta aplikasi hypnoteaching dalam pembelajaran.

\section{Hasil yang Dicapai dan Rencana Tindak Lanjut}

\section{Keberhasilan}

Secara umum kegiatan ini berjalan sukses. Hal ini bisa dilihat pertama, fasilitator hadir semua sesuai dengan jadwal. Mereka juga menyampaikan materi yang dilengkapi dengan makalah atau bahan bacaan yang relevan sehingga memudahkan peserta untuk menerima dan memahami materi. Kedua, para peserta hadir semua, sesuai dengan quota yang ditetapkan, yaitu keluarga besar MI Nurul Karim NW Kebon Ayu-Gerung, Kabupaten Lombok Barat sejumlah 15 orang guru dengan rincian 5 orang guru berlatar pendidikan S1 non kependidikan dan 10 orang belum berkualifikasi S1. Sehingga peserta berasal dari semua unsur yang diharapkan dapat menyukseskan program pembinaan kompetensi pedagogis guru berbasis keterampilan dasar mengajar ini. Semua peserta dengan antusias mengikuti kegiatan dari awal sampai akhir. Fasilitas yang disediakan panitia dan pihak MI Nurul Karim NW Kebon Ayu-Gerung, Kabupaten Lombok Barat cukup memadai sehingga turut memperlancar kegiatan ini.

\section{Hambatan-Hambatan}

Secara prinsip tidak ada hambatan yang berarti. Namun demikian ada beberapa catatan untuk diperhatikan.

a. Dari segi dana: Kegiatan ini hendaknya didukung dengan dana yang lebih cukup memadai, sehingga panitia dapat konsentrasi secara penuh pada pelaksanaan kegiatan. Terlebih, kegiatan ini akan lebih maksimal berjalan jika setelah pelatihan dan pendampingan, diselingi dengan karyawisata ke sekolah/ madrasah yang lebih maju yang telah lama berhasil menerapkan kompetensi pedagogis guru berbasis keterampilan dasar mengajar serta implementasi hypnoteaching dalam pembelajaran seperti SMAN 01 Mataram, MAN 1 Mataram, dan MAN 2 Mataram.

b. Dari segi peserta: perlu mempersiapkan secara maksimal field note atau jurnal sebagai persyaratan yang telah ditetapkan panitia, sehingga membantu panitia dalam dokumentasi bukti fisik kegiatan.

c. Dari segi instansi terkait: perlu mendukung kegiatan positif semacam ini dengan dukungan moril dan materilnya.

\section{Rencana Tindak Lanjut}

Rencananya kegiatan pembinaan yang mencakup pembekalan-pelatihan dan pendampingan ini akan diadakan secara berkala tiap tahun dengan peserta tidak saja berasal dari kalangan guru di lingkungan MI Nurul Karim NW Kebon Ayu-Gerung, Kabupaten Lombok Barat, namun diperluas ke sekolah/madrasah-madrasah lain yang menghajatkannya di wilayah Provinsi Nusa Tenggara Barat, selama Pimpinan UIN Mataram, khususnya melalui LP2M, tetap memberikan support-nya, baik moril maupun materiil. 


\section{Kesimpulan}

Kegiatan pemberdayaan Kompetensi Pedagogis Guru Berbasis Keterampilan Dasar Mengajar dan Metode Hypnoteaching di MI Nurul Karim NW Kebon Ayu-Gerung, Kabupaten Lombok Barat ini telah berjalan dengan lancar, lengkap dengan kelebihan dan kekurangannya. Perlu menjadi catatan agar laporan ini bisa menjadi pegangan untuk dibaca, dikritisi serta diikuti yang baik dan dieliminir yang kurang baik. Harapan juga, semoga pelatihan dan kegiatan pembinaan yang telah selesai ini mampu membekali para peserta dengan berbagai pengetahuan dan pengalaman dalam soal peningkatan kualitas penguasaan secara teori dan praktik terkait kompetensi pedagogis guru berbasis keterampilan dasar mengajar serta metode hypnoteaching, sehingga dapat mendorong mereka untuk menjadi tenaga pengajar yang profesional dan handal.

\section{Referensi}

Abdul Rahman shaleh, Pendidikan Agama \& Pembangunan Watak Bangsa, (Jakarta: PT Raja Grafindo Persada, 2005).

Abu Ahmadi dan Nur Uhbiyati, IImu Pendidikan, (Jakarta: Rineka Cipta, 1991).

Azhar Arsyad. Media Pembelajaran. (Jakarta: PT Raja Grafindo Persada, 2008).

Dimyati dan Mudjiono, Belajar dan Pembelajaran (Jakarta: Rineka Cipta, 1999).

Djamarah dan Saiful Bahri, Guru dan Anak Didik dalam Interaksi Edukatif(Jakarta: PT Rineka Cipta, 2005).

E. Mulyasa, Menjadi Guru Profesional (Bandung: Remaja Rosdakarya, 2005).

Fachruddin Saudagar dan Ali Idrus. "Pengembangan Profesionalitas Guru". (Jakarta: Gaung Persada (GP Press), 2009).

Hanafiah dan Cucu Suhana, Konsep Strategi Pembelajaran, (Bandung : PT Refika Aditama, 2010).

H.A.R. Tilaar, Perubahan Sosial dan Pendidikan: Pengantar Pedagogik Transformatif untuk Indonesia (Jakarta: PT Grasindo, 2002).

Muhammad Noer, Hypno Teaching for Succes Learning (Yogyakarta: Pustaka Insan Madani, 2010).

Nurrahmah, Potret Buram Pendidikan Daerah Miskin di Indonesia: Becermin dari Dompu Nusa Tenggara Barat (Mataram: Insan Madani Institute Mataram, 2014).

N. Yustisia, HYPNOTEACHING: Seni Mengeksplorasi Otak Peerta Didik (Jogjakarta: Ar-Ruzz Media, 2012).

Novian Triwidia Jaya, Hypno Teaching "Bukan Sekedar Mengajar"(Bekasi: D-Brain, 2010).

Robinson Situmorang, "Strategi Pembelajaran Berbasis Multiple Intelligence (MI) untuk Pencapaian Kompetensi dalam Pembelajaran", dalam Mozaik Teknologi Pendidikan, eds. Dewi Salma Prawiradilaga dan Eveline Siregar (Jakarta: Kencana, 2008).

Soetjipto dan Kosasi, Profesi Keguruan (Jogjakarta: CV Wicaksaana, 2012).

Suyanto dan M.S. Abbas, Wajah dan Dinamika Pendidikan Anak Bangsa (Yogyakarta: Adicita Karya Nusa, 2004).

Tim FKIP, Pemantapan Kemampuan Mengajar (PKM)- PGSD (Jakarta: Universitas Terbuka, 2008).

Yudhi Munadi, Media Pembelajaran (Sebuah Pendekatan Baru). (Jakarta: Gaung Persada (GP), 2012). 